\title{
Editorial for special issue on education and humour: Education and humour as tools for social awareness and critical consciousness in contemporary classrooms
}

\author{
Raúl Alberto Mora \\ Universidad Pontificia Bolivariana \\ raul.mora@upb.edu.co
}

\section{Simon Weaver}

Brunel University London

simon.weaver@brunel.ac.uk

\section{Laura Mae Lindo \\ Wilfrid Laurier University \\ decided@ hotmail.com}

Keywords: education, comedy, humour, social awareness, critical consciousness.

\section{Introduction}

It is not new to consider the instructive power of humour. Both Plato and Aristotle, through their superiority theories, saw the benefit of wit as a social corrective, although they remained suspicious of the uneducated laughter of the masses (Plato in Morreall 1987; Aristotle in Morreall 1987). This approach has informed traditions of satire and resistance humour in a myriad of contexts. Stott summarises the raison d'être of satire through its aim "to denounce folly and vice and urge ethical and political reform through the subjection of ideas to humorous analysis" (Stott 2005: 109). The political potential of humour is easily recognised as a rhetorical and communicative device, yet it seems odd that little stock has been placed academically or culturally in the idea of humour as an educative tool in other social and cultural contexts and, more specifically, in the classroom. It is this gap that this special issue seeks to address. It was, for a very long time, easy to see the presence of a Platonic "corrective" ridicule in many 
educational settings, while the rebellious, revolutionary, carnivalesque laughter of the learner would be suppressed without hesitation. This special issue, however, does not focus upon the use of humour as ridicule in the classroom, although such uses of humour are examined in some of the papers. Rather, it is concerned with the collaborative, convivial, more productive uses of humour as an educative tool, particularly as a tool to elicit debate and discussion on contemporary social and cultural issues and to encourage social awareness and conscientisation, or critical consciousness.

This is a collection of international papers on the roles that humour can play in education. It brings together authors from Australia, Canada, Colombia, the USA, and the UK. Consequently, the special issue is a collaborative effort, and while collaborative efforts come in many shapes and sizes, this particular special issue is, in many ways, a reflection of the "superdiverse" societies we live in (Blommaert \& Rampton 2011), one where the differences in social locations are (re)connected through a belief that humour in the classroom is particularly effective and new forms of affinities are developed (Black 2009; González Lopera 2015; Mora 2013a, 2014). Modern technology makes the creation of such networks a more expedient process. The papers comprising this issue were first presented as a panel at the Ninth International Congress of Qualitative Inquiry at the University of Illinois, Urbana-Champaign (Mora 2013b). The panel was judged a success and reinforced the collegial bonds among the authors. Issues of relevance for the authors emerged from the panel in relation to the new ways in which all the authors have tackled humour as an educational tool. All the presentations showed the need to look more deeply at these issues from a contemporary perspective. Thus the process of taking part in the panel critically developed the ideas in this special issue.

This special issue is important because it provides evidence of underexplored ways of thinking about, and practically applying, humour in educational settings. In fact, the dominance throughout history of superiority theories of humour, a dominance that was not automatically negated with the emergence of bourgeoisie incongruity theory or medicalised release theory, might, in a climate of critical humour studies, truly be juxtaposed through equality theories of humour. It is this concern, broadly speaking and in different forms, that drives the contributions to this special issue. There are social and cultural contexts in which humour is specifically not used to generate superiority.

\section{Reviewing the links between education and humour: A review}

Humour is an important tool for conveying multiple forms of messages, ranging from simple casual observations about daily life to more serious social denouncements of political and social inequality. Humour is thus rhetorical. In the field of education, questions have arisen about how to use humorous messages as tools to foster learning and bring social and cultural issues into the classroom. Some authors have called for the use of humour as a powerful psychological tool in the classroom (Garner 2006; Tziatis 2012; Seidman \& Brown 2013). Some effects of humour found in the literature include the facilitation of learning (Seidman \& Brown 2013), the promotion of more relaxed learning environments that support interactions among students (Tziatis 2012), and fostering student retention (Garner 2006). There is also evidence of the pedagogical benefits of humour. Hurren (2005, 2006), for instance, posited that humour in the classroom may encourage more attention, creativity, critical thinking and social contact. Both Lindo (2010) and Mayo (2008) argued that humour may be an excellent entry point in today's classrooms to engage in discussions of social justice issues such as race. In light of such work, 
Gordon $(2011,2012)$ argues that philosophers of education need to stop neglecting discussions about humour and, instead, embrace its potential in education. The articles in this special issue follow much of this work but bring a strong emphasis on humour as a tool for the development of social awareness and critical consciousness. But what do the authors mean by social awareness and critical consciousness? For this, we can turn to some examples of media comedy.

One interesting example of the links between humour and performance as tools to elicit an understanding of critical consciousness is present in the work of Taylor Mali, a former middle school teacher turned slam poet and humourist. In his humorous and satirical approach to poetry, Mali offers a defence of the importance of good teaching in a time when insidious marketisation of not just education but the entire public sphere, seeks to judge pedagogy through purely quantifiable outputs. Mali has brought attention to teachers' lives in "What teachers make" (Mali 2002c) and stressed the need to pay attention to language in "The the impotence of proofreading" (Mali 2002a) and "Totally, like, whatever, you know?" (Mali 2002b).

What Mali offers is not just social awareness but the critical consciousness needed to reply to the social discourses, ideologies or frames that create the "commonsense" of today. In the sketch "What teachers make" (Mali 2002c), for instance, he does this through a reply to a dinner party guest who happens to be a lawyer. The sketch emphasises the importance of education for the sake of education and explains that "teachers make a difference". "Totally, like, whatever, you know?" (Mali 2002b) turns into a scathing critique of the lack of conviction present in today's discourse and invites listeners, through the mockery of the pseudo-interrogative tone folks use today, to "speak with conviction" and have strong beliefs. Finally, in "The the impotence of proofreading" (Mali 2002a), Mali questions the overreliance on spellchecking and makes a poignant argument, mostly through double-entendres, about the dangers of letting word processors take over our critical thinking processes when writing.

The African American comedian, Dave Chappelle, is also recognised for mobilising his comedy to promote critical consciousness through both sketch and stand-up comedy. Examples of his critical engagement with race and his unpacking of hegemonic allegiance to anti-Black racism abound, and it has been argued that his work educates in the public realm. With today's resurgence of interest in addressing the over-policing of African Americans in the USA, for example, Chappelle's discussion of his White Friend Chip in his HBO special Killin' Them Softly (Chappelle 2000) is of particular relevance because it challenges audiences to think critically about how policing works in contemporary society. Chappelle's story begins with describing the ease with which his White friend Chip asks a police officer for directions while under the influence of marijuana. Chappelle explains that the officer provides Chip with the necessary information with little to no concern over Chip being high, despite Chip touching the officer while confessing, "I'm a little high, all I want to know is, which way is Third Street?" Chappelle continues, explaining to the silent audience, "That's all that happened. That's the end of the story". They erupt into laughter, at some level sharing his understanding of the irony of the officer's response. Chappelle explains that, although this story may not be outstanding for White people, a Black person would never believe that they could speak to a police officer under similar conditions. By introducing the audience to his White Friend Chip, then, Chappelle begins to educate his audience about the relationship between Black Americans and the police. To this end, Chappelle continues, confessing to his audience, "That's how it is, but at the time I didn't think there was anything racial about it". Like many people of colour, recognising that overt differences persist between how Black and White Americans are policed is difficult to accept. 
To accentuate this difference in policing, Chappelle continues, explaining that he would be afraid to have to speak to the police even if he was sleeping. Imagining a police officer finding him asleep and "getting the wrong idea", Chappelle describes in great detail how the officer would immediately knock him out before turning to his partner to accuse Chappelle of being on PCP. "I had to use necessary force", Chappelle continues in character, "you saw him!" He finished off the skit in character, Chappelle continues, stating, "No... no... no paperwork. Just sprinkle some crack on him. Let's get out of here!" Today, with movements such as "Black Lives Matter" alongside "\#SayHerName" and "\#SayHisName" hashtags which ensure we do not forget the lives of Black Americans like Michael Brown killed in Missouri, Tamir Rice killed in Ohio, Eric Garner killed in New York City, Freddie Gray's killed in Baltimore, as well as Michelle Cusseau in Arizona, Rekia Boyd in Illinois and Sandra Bland in Texas, who lost their lives at the hands of local police, Chappelle's routine, met with uproarious laughter, holds within it veritable commentary on the continued aggression towards African Americans by citizens who represent the state. Thus, while the pain is real, the laughter holds an opportunity for education in public forums about what it means to be Black in America. Chappelle's use of comedy as pedagogy allows communities to engage with topics such as race and racism.

Although Taylor Mali and Dave Chappelle are mainstream examples, they illustrate the potential there is for researching the connections between comedy and education in ways that broaden both our understanding of viable pedagogical tools. Moreover, comedians like this continue to challenge commonly held notions of what education looks like and where education can (and, in some cases, should) happen. The special issue is concerned with how to use comedy as an alternative means to educate today's children, how to provide other critical means to think about teaching and what it means to become a teacher. The discussion that these articles portray is a much-needed antidote to the viewing of education through market driven, ideological lenses, especially in a time when the push for standardised testing seems to be the worldwide norm rather than the exception. Critical consciousness for the authors in this issue is largely explained through the ability to step outside of the contemporary discourse and provide a response on issues of social and cultural importance. Through the five articles that comprise this special edition, the authors explore what teachers and teacher educators from different countries are doing with comedy in educational settings.

\section{Education, humour and social activism: Article summaries}

The five articles that comprise this issue share the common theme of the educational value of humour to raise social awareness and critical consciousness. Indeed, the nexus among humour, comedy and a concern for issues became the proverbial glue that brought the articles together. Each article approaches this task from a different direction. Most of the articles draw on data collected on teaching practice in education settings (Bright this issue; Lindo this issue; Lovorn \& Holaway this issue) and some combine teacher education and secondary education arenas (Di Niro \& Muslera this issue; Rice \& Rice this issue). The sources of comedy are diverse, and include racial comedy (Lindo this issue), viral videos (Bright this issue), stage performances (Di Niro \& Muslera this issue), interactions with students (Rice \& Rice this issue), and interactions with other teachers (Lovorn \& Holaway this issue).

The methodologies employed are equally diverse. The articles use a variety of quantitative and qualitative methods, such as content analysis (Lovorn \& Holaway this issue), discourse analysis (Bright this issue), qualitative observations and interviews (Di Niro \& Muslera this

Open-access journal| www.europeanjournalofhumour.org 
issue), and classroom intervention techniques (Lindo this issue). The theoretical or conceptual frameworks also provided a broad palette. Theoretical backgrounds and concepts include ideas of cultural capital (Rice \& Rice this issue), ideas of social justice and privilege (Bright this issue), the notion of humour as a classroom strategy (Lovorn \& Holaway this issue), critical race theory (Lindo this issue), and the Italian performance style of Commedia dell'Arte (Di Niro \& Muslera this issue).

This diversity of ideas and notions becomes, then, an important resource for international researchers that are seeking methodologies and conceptual frameworks that might break the boundaries of what constitutes acceptable or comfortable discourse and turn classrooms into a place where learning is more experiential and critical. The authors intend to show us how humour opens spaces for interaction (Di Niro \& Muslera this issue; Lovorn \& Holaway this issue), advocacy (Lindo this issue; Rice \& Rice this issue) and social activism (Bright this issue), which are increasingly important in the face of pedagogical discourse in favour of functional and test-based practices.

In the lead article, Mary and Brian Rice offer insight into narratives of teacher advocacy for children through the lens of literary comedy, with particular attention to the comedic trickster trope. Using this frame, the authors argue that current teacher education practices described in research literature provide little guidance for teacher candidates moving into school systems and trying to develop and maintain a stance of advocacy. These authors' experiences, as filtered through the lens of comedy, also demonstrate that helping teacher candidates to consider their interactions with students through cycles of absurdity, tragedy, resurrection, and integration, enabled them to sustain novices as well as to feel sustained in their own work.

For the next article, Michael Lovorn and Calli Holaway focus on teachers' uses of humour as an instructional enrichment and classroom management strategy. Through online discussions, the author orchestrated an invigorated conversation among 31 classroom teachers wherein they were encouraged to share their perspectives on how student learning, engagement and motivation are impacted by the use of humour. Lovorn and Holaway also asked these teachers to share their thoughts on what impact humour has on their interaction with students as well as various challenges and resistances to the use of humour in the classroom. Their findings showed colourful and revealing responses from the participants. This paper highlights their examples of uses of humour in the classroom, as well as their perspectives on impromptu vs. structured use of humour in their teaching.

In the next article, Anita Bright raises two important questions: (a) What role might humour play in the professional preparation of future educators? (b) How might levity, laughter or lightness serve a purpose in pushing their understandings, deepening their thinking and inviting new perspectives? By employing critical discourse analysis and framing funny videos as part of larger, cultural "mirror" that reflects widely-held values and beliefs within local, institutional and societal domains, Bright identifies specific humorous videos and lines of inquiry that have supported educators in recognising their own complicity in promoting a narrow definition of normativity. This normativity ranges along varying and intersecting planes, including white privilege, the privilege of being a heritage speaker of English, privileged gendered behaviours, heteronormativity, and the myth of meritocracy, among others. With a press to guide future educators in identifying their own positionalities within the context of power, privilege, and education, this work seeks to invite new thinking into how humorous media may be leveraged to enrich the work of the teaching force. 
Our next article looks at how Laura Mae Lindo advocates for the continued need to make discourses of race and racism explicit in educational settings in Canada. To this end, she presents and describes the work of "Race Comics" qua anti-racist educators and introduces the benefits of incorporating the comedic material of comedians like Chris Rock and Dave Chappelle in teacher education classrooms. Drawing on personal reflections of this pedagogical strategy in Canadian teacher education classrooms in Ontario (Canada) and Prince Edward Island (Canada), her paper teases out the ways in which these comedic texts in particular provided developing teachers with an opportunity to reflect upon their own normalised racial discourses, highlighting how these interfered with their ability to be the "perfect teacher". She concludes with a discussion of comedy's ability to help those devoted to developing socially just educational pedagogies to speak freely about their own normalised prejudices.

Finally, in the Australian context, Corinna Di Niro and Paulo Muslera focus on new ways in which Commedia dell'Arte might be tackled as part of the secondary school curriculum in Australia. Through interviews with Commedia dell'Arte practitioners and drama teacher observations, the authors provide a deeper insight into the misconceptions of the genre and of the aims and objectives of the school curriculum. It provides a strategy to make teaching Commedia dell'Arte more manageable with respect to the curriculum and more beneficial for the students. The article draws on a practice-led research whereby an entirely new Commedia dell'Arte performance was devised to suit a contemporary Australian context: The Marriage of Flavio and Isabella. The authors also discuss the balance between retaining genre characteristics and the need to update it as a concerted effort to create a performance relevant to an Australian context.

\section{Conclusion: Challenges for education and humour - Some implications from the articles}

The authors involved in this special issue share a strong belief, as manifested in all of the articles: humour can be a very powerful tool in the classrooms, yet there is a great deal of uncharted territory when translated to the curriculum. All articles identify with humour's potential to unearth counter-narratives (Mora 2014) and contest conventional wisdom in our classrooms. Humour is a veritable resource to, using Rice and Rice's word, "unpack" stories and even beliefs (Bright this issue) in our classrooms.

Using and sharing humorous stories and media can help enhance a sense of voice and advocacy in our teachers while defying traditional or "normal" (Bright this issue) constructions of society and race (Lindo this issue). Humour can also help teachers explore and question archetypes (Di Niro \& Muslera this issue) and stereotypes (Lindo this issue), as a first step toward stronger advocacy efforts (Rice \& Rice this issue). However, as Lovorn and Holaway (this issue) cautioned, we must also develop frameworks to help students develop sensible limits to their humorous remarks. As recent examples in comedy and society have showed, people today are less willing to give comedians and public spokespeople a free pass when it comes to racial insensitivity or derogatory remarks for the sake of eliciting laughter or shock value. The aim of equality over superiority needs to be carefully maintained.

There is a second point of convergence that all articles offer that also becomes a loud call for action. All these efforts to integrate comedy and pedagogy at the higher education (Bright this issue; Lindo this issue; Rice \& Rice this issue) and at the secondary curriculum (Di Niro \& Muslera this issue; Lovorn \& Holaway this issue) need to move from exciting and valiant efforts 
from socially-conscious teachers and teacher educators into systematic work. We need pedagogical initiatives where humour is less serendipitous or happenstance (Lovorn \& Holaway this issue) and becomes a more organised effort that practitioners feel more comfortable using in their classrooms.

As these five articles show, the potential for humour in 21 st century classrooms is rather untapped and open to a wide range of possibilities. As educational systems gravitate towards economy-driven standardisation, we as a community of educators, researchers, and advocates need to rise above this and develop a sense of counter-hegemony (Gramsci 1971) in our classrooms and curricula. These authors have provided a potential blueprint between the lines of their manuscripts. They are inviting us to provoke our students into thinking, into consciousness, into advocacy. They have showed us ways for how, through performance, viral videos, or literature, our students and teachers can use humour to become tricksters (Vizenor 1988) and agent provocateurs in their schooling practices. These articles advocate for stronger voices through humour so that our students and teachers can find true agency. In that spirit, we will end this introduction to the five articles in this issue with Taylor Mali's (2002b) invocation.

I entreat you, I implore you, I exhort you,

I challenge you: To speak with conviction.

To say what you believe in a manner that bespeaks

the determination with which you believe it.

Because contrary to the wisdom of the bumper sticker,

it is not enough these days to simply QUESTION AUTHORITY.

You have to speak with it, too.

\section{References}

Banas, J. A., Dunbar, N., Rodriguez, D., \& Liu, S. (2011). 'A review of humour in educational settings: Four decades of research'. Communication Education 60 (1), pp. 115-144.

Black. R. W. (2009). 'English-language learners, fan communities, and 21st-century skills'. Journal of Adolescent \& Adult Literacy 52 (8), pp. 688-697.

Blommaert, J. \& Rampton, B. (2011). 'Language and superdiversity'. Diversities 13 (2), pp. 121.

Chappelle, D. (2000). Killin’ Them Softly. Washington, D.C.: Urban Works.

Garner, R. L. (2006). 'Humour in pedagogy: How ha-ha can lead to aha!'. College Teaching 54 (1), pp. 177-180.

González Lopera, C. A. (2015). Exploring Digital Literacies in Second Language Acquisition to Develop Critical Reading. Medellín: Universidad Pontificia Bolivariana MA thesis.

Gordon, M. (2010). 'Learning to laugh at ourselves: Humour, self-transcendence, and the cultivation of moral virtues'. Educational Theory 60 (6), pp. 735-749.

Gordon, M. (2012). 'Humour, laughter and educational philosophy'. Encounter 25 (2), pp. 9-15.

Gramsci, A. (1971). Selections from the Prison Notebooks. Ed. and transl. by Hoare, Q. \& Nowell Smith, G. London: ElecBook.

Hurren, B. L. (2005/2006). 'Humour in school is serious business'. International Journal of Learning 12 (6), pp. 79-83.

Lems. K. (2011). 'Pun work helps English learners get the joke'. The Reading Teacher 65 (3), pp. 197-202. 
Lindo, L. M. (2010). 'Comic revelations'. Our Schools/Our Selves 19 (3), pp. 185-198.

Mali, T. (2002a). 'The the impotence of proofreading'. Available online: https://www.youtube.com/watch?v=OonDPGwAyfQ [Accessed on 28 October 2015].

Mali, T. (2002b). 'Totally, like, whatever, you know?'. Available online: https://www.youtube.com/watch?v=LGAMd-tT6fQ [Accessed on 28 October 2015].

Mali, T. (2002c). 'What teachers make'. Available online: https://www.youtube.com/watch?v=RxsOVK4syxU [Accessed on 28 October 2015].

Mayo, C. (2008). 'Being in on the joke: Pedagogy, race, humor'. Philosophy of Education, pp. 244 -52. Available online: http://ojs.ed.uiuc.edu/index.php/pes/article/view/1372/122 [Accessed 28 October 2015].

Mora, R. A. (2009). 'Critical race comedy: Racial comedy's contributions to CRT discourse and its counternarratives'. Paper presented at the Fifth International Congress of Qualitative Inquiry. Urbana, 20-23 May.

Mora, R. A. (2013a). 'The notion of second languages: Responding to today's linguistic ecologies'. The Journal for ESL Teachers and Learners II, pp. 53-61.

Mora, R. A. (2013b). 'Revisiting the links between education and humour'. Panel conducted at the Ninth International Congress of Qualitative Inquiry. Urbana, 15-18 May.

Mora, R. A. (2014). 'Counter-narrative'. Key Concepts in Intercultural Dialogue, 36. Available online: https://centerforinterculturaldialogue.files.wordpress.com/2014/10/key-conceptcounter-narrative.pdf [Accessed on 28 October 2015].

Morreall, J. (ed.) (1987). The Philosophy of Humour and Laughter. Albany: State University of New York Press.

Pomerantz, A. \& Bell, N. D. (2011). 'Humour as safe house in the foreign language classroom'. Modern Language Journal 95, pp. 148-161.

Seidman, A. \& Brown, S. C. (2013). 'College classroom humour: Even the pundits can benefit'. Education 133 (3), pp. 393-395.

Stott, A. (2005) Comedy. New York and London: Routledge.

Tziatis, D. (2012). 'Humour as an outdoor educator's tool'. Pathways: The Ontario Journal of Outdoor Education 24 (2), pp. 35-36.

Vizenor, G. (1988). The Trickster of Liberty. Tribal Heirs to a Wild Baronage. Minneapolis: University of Minnesota Press.

Ziyaeemehr, A., Kumar, V., \& Abdullah, M. (2011). 'Use and non-use of humour in academic ESL classrooms'. English Language Teaching 4 (3), pp. 111-119. 